IZA DP No. 5447

Workplace Performance, Worker Commitment and Loyalty

Sarah Brown

Jolian McHardy

Robert McNabb

Karl Taylor

January 2011 


\title{
Workplace Performance, Worker Commitment and Loyalty
}

\author{
Sarah Brown \\ University of Sheffield \\ and IZA
}

Jolian McHardy

University of Sheffield

Robert McNabb

Cardiff University

Karl Taylor

University of Sheffield

and IZA
Discussion Paper No. 5447
January 2011

IZA

P.O. Box 7240

53072 Bonn

Germany

Phone: +49-228-3894-0

Fax: +49-228-3894-180

E-mail: iza@iza.org

Any opinions expressed here are those of the author(s) and not those of IZA. Research published in this series may include views on policy, but the institute itself takes no institutional policy positions.

The Institute for the Study of Labor (IZA) in Bonn is a local and virtual international research center and a place of communication between science, politics and business. IZA is an independent nonprofit organization supported by Deutsche Post Foundation. The center is associated with the University of Bonn and offers a stimulating research environment through its international network, workshops and conferences, data service, project support, research visits and doctoral program. IZA engages in (i) original and internationally competitive research in all fields of labor economics, (ii) development of policy concepts, and (iii) dissemination of research results and concepts to the interested public.

IZA Discussion Papers often represent preliminary work and are circulated to encourage discussion. Citation of such a paper should account for its provisional character. A revised version may be available directly from the author. 


\begin{abstract}
Workplace Performance, Worker Commitment and Loyalty ${ }^{*}$

Using matched employer-employee level data drawn from the 2004 UK Workplace and Employee Relations Survey, we explore the determinants of a measure of worker commitment and loyalty $(C L I)$ and whether $C L I$ influences workplace performance. Factors influencing employee commitment and loyalty include age and gender, whilst workplace level characteristics of importance include human resource practices. With respect to the effects of employee commitment and loyalty upon the workplace, higher CLI is associated with enhanced workplace performance. Our findings that workplace human resources influence $C L I$ suggest that employers may be able to exert some influence over the commitment and loyalty of its workforce, which, in turn, may affect workplace performance.
\end{abstract}

JEL Classification: J20, J50

Keywords: commitment, financial performance, labor productivity, loyalty

Corresponding author:

Karl Taylor

Department of Economics

University of Sheffield

9 Mappin Street

Sheffield S1 4DT

United Kingdom

E-mail: k.b.taylor@sheffield.ac.uk

\footnotetext{
* We are grateful to the Data Archive at the University of Essex for supplying data from the 2004 Workplace and Employee Relations Survey. We are also grateful to the Co-editor, two anonymous referees, as well as Andy Dickerson, Steven McIntosh and Stephen Wood for valuable comments and advice. We are also grateful to participants at the Work and Pensions Economics Group Annual Conference, Nottingham, July 2009, for excellent comments. The normal disclaimer applies.
} 


\section{Introduction}

A large empirical literature exists which explores the determinants of organizational performance. For example, Machin and Stewart (1990), McNabb and Whitfield (1998) and Munday et al. (2003) examine the determinants of financial performance, whilst Griliches and Regev (1995), Oulton (1998) and Griffiths and Simpson (2004) focus on the determinants of labor productivity. Many such studies are based on firm level data. One might argue, however, that, in order to understand the determinants of firm performance, it is important to also analyze employee level information given that the behavior of employees and the decisions they make may influence workplace performance. In this paper, we investigate whether the level of employee attachment to the organization influences workplace performance using matched employer-employee data. To be specific, we seek to ascertain whether worker commitment and loyalty influence labor productivity and financial performance at the firm level. In addition, we explore the determinants of such employee attitudes towards the organization for which they work in order to establish how such attachments may be fostered.

The concept of organizational commitment has attracted a great deal of interest in the human resource management and psychology literatures. For example, employee commitment and loyalty are central features in the high performance workplace literature in which they are seen as mediating factors linking different types of human resource management and employment practices to enhanced performance. In this paper, we focus on affective commitment, which, according to Meyer and Allen (1991, p.67) refers to the "... employee's emotional attachment to, identification with, and involvement in the organization." They continue (op.cit.) "Employees with a strong affective commitment 
continue employment with the organization because they want to do so."1 Meyer et al. (1993, 2002) argue that strong affective commitment to an organization arises because employees share values with both the organization and its members and it is therefore predicted to be positively associated with job performance. Moreover, establishing a committed and loyal workforce may be associated with enhanced firm performance through less opportunistic behavior on the part of employees (Green, 2008) or through influencing their supply of effort, and hence output. Employees' decisions over their supply of effort play a key role in various incentive models of worker compensation (see, for example, Lazear, 2000) as well as in the efficiency wage literature (see Akerlof, 1982 and Akerlof and Yellen, 1990). Given such a relationship between employee effort and commitment, an interesting line of enquiry concerns how the firm may influence the level of affective commitment via human resource (HR) practices.

Employee commitment and loyalty thus arguably play an important role in the principal-agent issues surrounding the separation between the ownership and control of an organization. The costs associated with delegated decision-making clearly depend on the extent to which the interests of the principal and agent differ (see, for example, Aghion and Tirole, 1997, and Athey and Roberts, 2001). In so far as employees who exhibit commitment and loyalty towards their employer may have interests which are aligned with those of their employer, the agency costs often associated with the employee-employer relationship are reduced. One attempt to construct an economic model of identity and work incentives, thus capturing such motivations, is Akerlof and Kranton (2005), whose analysis, within a principal-agent framework, suggests that instilling in employees "a sense of identity and

\footnotetext{
${ }^{1}$ Meyer and Allen (1991) introduce a three-component model of organizational commitment. In addition to affective commitment, according to Meyer et al. (1993, p.539), employees "with a strong continuance commitment remain [with the organization] because they need to, and those with a strong normative commitment remain because they feel they ought to do so." Though, in their the review of the Workplace and Employee Relations Survey (WERS) 2004, Bewley et al. (2010) recommend extending the questionnaire in WERS 2011 to include both normative and continuance commitment, WERS 2004, on which our paper is based, includes only affective commitment, limiting our study accordingly.
} 
attachment to an organization is critical to well-functioning enterprises" (op. cit., p. 11). We introduce and apply their framework in our theoretical discussion below.

Given that the degree of commitment and loyalty of employees towards their employer is fundamentally linked to the way in which employees conduct themselves at the workplace, as well as the agency considerations that underpin the relationship between employees and employers, it is surprising that employee commitment and loyalty have attracted only limited attention in the economics literature. In the following section we outline a theoretical framework to explain the link between HR practices, affective commitment and worker and firm performance in the context of the principal-agent problem. In the empirical analysis which then follows, we firstly explore the determinants of affective commitment at the employee level with the focus on how HR practices influence such commitment. Secondly, we explore the implications of employee commitment and loyalty for financial performance and labor productivity at the firm level, which contrasts with the focus in the management and psychology literatures, which have tended to focus on the relationship between employee commitment and job performance rather than firm performance.

\section{Theoretical Framework}

In this section we discuss a theoretical rationale for our empirical findings of a positive link between various $\mathrm{HR}$ practices and worker commitment through to improved firm performance. Our theoretical approach has two parts. We begin by setting out the theoretical channels (supported by empirical evidence) through which HR practices influence affective commitment. We then demonstrate that the positive link between affective commitment and firm performance can be explained as a logical prediction of the principal-agent model developed to include affective commitment. ${ }^{2}$

\footnotetext{
2 Though indicating theoretical channels through which HR practices may influence firm performance via worker commitment, our discussion is not intended to be exhaustive.
} 


\subsection{Affective Commitment and Loyalty}

Numerous authors have identified links between HR practices and affective commitment. Of the various factors recognized as having an influence on affective commitment, those relevant to the present study (and discussed in more detail below) are organizational communication, raising commitment through empowerment of the employee (e.g. Stuart, 1999) or though employee participation and involvement (e.g. Cotton et al., 1998) and the establishment of organizational trust (e.g. Mayfield and Mayfield, 2002).

\section{Organizational Information and Communication}

The process by which employees are made aware of organizational goals and their involvement in the achievement of them is recognized to play an important role in fostering job commitment (e.g., Anderson and Martin, 1995; Haskins, 1996). Goris et al. (2000) and Ooi et al. (2006) find organizational communication to have an important positive association with affective commitment, whilst Brunetto and Farr-Whartons' (2004, p.594) findings “... suggest a strong relationship between communication processes and job satisfaction and affective job commitment...".

\section{Employee Involvement and Participation}

Employee participation, which includes such things as involvement in joint decision making, has been shown to have a positive association with positive work attitudes and employee commitment (e.g. Cassar, 1999). Ooi et al. (2006), who find a positive association between employee participation and affective commitment, note the positive effects of participation on job satisfaction, changing certain personality characteristics of employees. As we will see later, the idea of policies aimed at altering personality characteristics plays a central role in the model of Akerlof and Kranton (2005), henceforth AK. 


\section{Organizational Trust}

Gilbert and Tang (1998, p.322) define organizational trust as “... a feeling of confidence and support in an employer; it is the belief that an employer will be straightforward and will follow through on commitments". Various researchers have found organizational trust to be a significant predictor of organizational commitment (e.g. Podsakoff et al., 1996, and Ashford et al., 1989), and specifically, affective commitment (e.g. Karia and Ahmad, 2000, and Ooi et al., 2006).

Ideally it would be possible to distinguish the influences of each of these factors on affective commitment. However, it appears that there is a strong interrelationship between information, involvement and organizational trust making such delineation difficult. For example, Mayfield and Mayfield (2002, p.90) observe that “...communication mechanisms for establishing and sustaining trust affect commitment". Hartmann and Bambacas (2000) argue that work experiences, such as role clarity, are related to the feeling of belonging which can further be linked to affective commitment. It seems logical to suppose that issues such as role clarity would be a function of both organizational communication and employee involvement. According to Mishra and Morrissey (1990), trust is inculcated by openness of communication, sharing decision making, critical information and perceptions and feelings with employees. As such communication, employee involvement and participation and trust are overlapping. Though in this paper we seek to determine the relative importance of each of these factors, the above discussion indicates their impact may be jointly determined. Indeed, our findings strongly support the joint significance of HR practices on affective commitment.

\subsection{Basic Principal-Agent Model}

In the principal-agent model, the principal (the employer) has an interest in inducing the agent (the employee) to undertake an action that is costly to the agent. The typical principalagent problem arises when (i) the principal is unable to observe what action the agent has 
taken, and (ii) it is not possible to infer the agent's action from an observation of the agent's output. The question is then one of how to define a payment contract that incentivises the agent to choose the costly action.

Let $a \in A$ be the action of the agent, where $A$ is the agent's action set. Let $c_{a}$ be the cost to the agent of action $a$. For simplicity, we restrict the discussion to two distinct actions: $\alpha, \beta \in A$, where $\alpha$ is the principal's preferred action but $c_{\alpha}>c_{\beta}$. In line with condition (i) we assume asymmetric information: the agent knows which action is undertaken but the principal does not. Now, suppose that the agent's output, $x$, is a function of its action, $x=x(a)$ and that the function is known to the principal. Condition (ii) now requires that $x=x(a)$ is not one-to-one. A standard way to achieve this is by assuming that output can take on a finite number of possible levels: $x_{i} \in X(i=1, \ldots, n)$ and that $\pi_{i a}$ is the probability that output $x_{i}$ will be observed given that the agent's action is $\sum_{i=1}^{n} \pi_{i a}=1$. We assume that the principal is risk-neutral and the agent is risk-averse. We describe the agent's preferences using a von Neumann-Morgenstern utility function which, for simplicity, is linear in action cost, so the expected utility for the agent under action $a$ is given by $u_{a}=\sum_{i=1}^{n} u\left(w_{i}\right) \pi_{i a}-$ $c_{a}$ where $w_{i}\left(x_{i}\right)$ is the payment contract employed by the principal. The principal's objective is then to solve:

$\max _{w_{i}} \sum_{i=1}^{n}\left(x_{i}-w_{i}\right) \pi_{i \alpha}$

s.t.

$$
\begin{aligned}
& \sum_{i=1}^{n} u\left(w_{i}\right) \pi_{i \alpha}-c_{\alpha} \geq \sum_{i=1}^{n} u\left(w_{i}\right) \pi_{i \beta}-c_{\beta} \\
& \sum_{i=1}^{n} u\left(w_{i}\right) \pi_{i \alpha}-c_{\alpha} \geq \bar{u}
\end{aligned}
$$

where $\bar{u}$ is the reservation level of utility, (2) is the incentive compatibility constraint and (3) is the participation constraint. 
So far, we have a standard representation of the principal-agent model in which the common interpretation of action $a$ is employee effort. We now develop the model slightly to allow us to accommodate a more sophisticated argument. Clearly anything that increases $\sum_{i=1}^{n} u\left(w_{i}\right) \pi_{i \alpha}$ relative to $\sum_{i=1}^{n} u\left(w_{i}\right) \pi_{i \beta}$ or reduces $c_{\alpha}$ relative to $c_{\beta}$, will promote action $\alpha$ over $\beta$. In the following Sections 2.3 and 2.4 we seek to explain how HR practices may influence this balance in favor of action $\alpha$ through inducing affective commitment. We address this point in the context of an extension to the principal-agent framework, first by augmenting the standard model to include information asymmetry regarding the costs and benefits of effort, and second by letting the net cost of effort depend upon the employee's identity.

\subsection{HR to Resolve Information Asymmetries}

We now consider how the HR factors introduced above may, through their effect on affective commitment, have a role in affecting, directly, the principal-agent decision framework yielding improved performance.

We begin by considering an extension of the principal-agent model in which there is a further information asymmetry beyond that assumed in the basic model (above). We suppose that the employer has full information about the probability distribution of returns to employee effort, $\sum_{i=1}^{n} u\left(w_{i}\right) \pi_{i a}$, and the associated costs, $c_{a}$, but the employee does not. For simplicity we consider the case where the employee knows the returns and costs associated with the lower level of effort, $\beta$, but not those associated with the higher level of effort, $\alpha .^{3}$ Instead, the employee has beliefs $\sum_{i=1}^{n} u\left(w_{i}\right) \tilde{\pi}_{i \alpha}$ about the distribution of returns and $\tilde{c}_{\alpha}$ about the costs under action $\alpha$ where $\sum_{i=1}^{n} u\left(w_{i}\right) \tilde{\pi}_{i \alpha}<\sum_{i=1}^{n} u\left(w_{i}\right) \pi_{i \alpha}$ and $\tilde{c}_{\alpha}>c_{\alpha}$. This reflects the idea that though the employer has full information about the costs and benefits of

\footnotetext{
${ }^{3}$ The focus on asymmetric information relating to the benefits and costs of effort level $\alpha$ is reasonable here given that we are assuming employees are making decisions about raising their level of effort from their 'current' low level $\beta$ (whose costs and benefits they currently experience and hence observe and understand) to the higher level $\alpha$.
} 
action $\alpha$ and may reveal this to the employee, the 'non-trusting' employee realises that the employer has an incentive to distort the information and underestimates the expected utility derived from the higher level of effort and/or over estimates the associated cost of effort.

From inspection of (2) it is now clear that, against the backdrop of such informational asymmetry, improvements in HR organizational communication or employee involvement/ participation that help reveal to the employee the true rewards and costs of action $\alpha$ alongside an understanding of, or improvements in, organizational trust (and the willingness of the employee to revise $\tilde{\pi}_{i \alpha}$ and $\tilde{c}_{\alpha}$ ) will promote action $\alpha$ relative to $\beta$.

These points have been based on an extension of the asymmetric information in the principal-agent problem to include the employer having important information that the employee does not but that through pursuing HR practices that offer a combination of improved participation, communication and trust, has been partially resolved leading to better informed choices and higher productivity. However, we now explore a further possible way in which greater affective commitment may yield beneficial performance outcomes via another adaptation of the basic principal-agent model.

\subsection{HR to Influence Employee Identity}

There are a limited number of examples of attempts to model worker commitment and productivity in the economics literature. Green (2008) argues that, from an economist's perspective, affective commitment can be regarded as a proxy for the utility associated with working for the current employer as compared to doing the same job with the next best employer, thereby establishing firm-specific utility, which potentially plays an important role in employee decision-making and workplace behavior. AK attempt to formalize the link between commitment and effort (hence productivity) in the principal-agent framework. They do so by embracing concepts from management and psychology and attempting to fit them into a utility framework. We integrate their model in our discussion as follows. 
In the $\mathrm{AK}$ model employee utility is a function of the employee's identity and employee identity can be influenced by the practices of the organization. Suppose an employee can take an identity $d \in D$. For simplicity we consider two possible identities $N, O \in D$ where $N$ represents an 'insider' and $O$ represents an 'outsider'. In the AK framework, identity has an associated 'norm'. So an employee with identity $N$ works in the organization's interests (e.g. effort $\alpha$ ) and loses utility if they deviate from this action. Clearly, if $d=N$ then the organization experiences a reduction in the wage needed to stimulate action $\alpha$. AK essentially extend the principal-agent model (equations 1-3) by replacing the linear cost term $c_{a}$ in (2) with an expression that can be interpreted as a net cost of effort:

$c_{a}=e_{a}+t_{d}\left|e^{*}(d)-e_{a}\right|-I_{d}$

In (4) $e_{a}$ is the cost of the employee's 'actual' action (effort $a$ ), the term $I_{d}$ represents the utility that the employee gets from being in identity category $d$, whilst $t_{d}\left|e^{*}(d)-e_{a}\right|$ is the penalty associated with divergence from the employee's 'ideal' effort given their identity $d$, $e^{*}(d)$. AK's argument is then that the firm invests in inculcating the employee, building commitment, hoping to move an employee's identity from 'outsider' to 'insider', thereby eliminating the penalty associated with effort $\alpha$ and possibly raising $I_{d}$. Both of these effects reduce the 'net cost' term and hence raise the L.H.S. of (2) relative to the R.H.S. raising the prospect of the 'high' effort outcome.

In what follows, we firstly explore the determinants of affective commitment at the employee level with the focus on how HR practices influence such commitment. Secondly, we explore the implications of employee commitment and loyalty for financial performance and labor productivity at the firm level, which contrasts with the focus in the management and psychology literature, which is generally on the relationship between employee commitment and job performance rather than firm performance. 


\section{Data}

In order to explore the relationship between employee commitment, loyalty and firm performance, we analyse data from the 2004 Workplace and Employee Relations Survey (WERS). This is the fifth in a Government funded series of surveys conducted at British workplaces. The previous four surveys were conducted in 1980, 1984, 1990 and 1998, and prior to 1998, it was called the Workplace and Industrial Relations Survey (WIRS). The aim of these surveys is to provide nationally representative data on the current state of workplace relations and employment practices in Britain, and it is widely regarded as the principal source of information pertaining to changes in British industrial relations (Chaplin et al., 2005). The survey population for the 2004 WERS is all British workplaces with at least five employees except for those in agriculture, hunting and forestry, fishing, mining and quarrying, private households with employed persons, and extra-territorial organizations. The sample comprises 2,295 workplaces, whilst the sample used for our econometric analysis includes 1,432 workplaces due to missing data. The 2004 WERS has four main sections: the Worker Representative Questionnaire; the Financial Performance Questionnaire; the Management Questionnaire; and the Employee Questionnaire. The first three sections yield establishment level information, whilst the final section (the Employee Questionnaire) provides employee level information. The focus of our empirical analysis is upon the final two sections.

\section{Employee Questionnaire}

Up to 25 employees from each workplace were asked to complete the Employee Questionnaire yielding a sample of 17,208 employees after conditioning on missing data. The Employee Questionnaire contains information on a number of measures of employees' attitudes towards both their jobs and their workplaces. In particular, employees are asked to indicate how strongly they agree or disagree with each statement: (i) I share many values of 
my organization and (ii) I feel loyal to my organization. Responses to the former yield information pertaining to the individual's commitment to their employer $(c),{ }^{4}$ whilst responses to the latter indicate the level of the individual's loyalty to their organization $(l)$. From this information, we have constructed two five point indices where 4 (0) represents the maximum (minimum) extent to which individuals agree with the above statements. The indices are defined as follows:

$c_{w i}=\left\{\begin{array}{l}4=\text { strongly agree }(12.09 \%) \\ 3=\text { agree }(43.43 \%) \\ 2=\text { neither agree } / \text { disagree }(32.69 \%) \\ 1=\text { disagree }(9.21 \%) \\ 0=\text { strongly disagree }(2.58 \%)\end{array} \quad l_{w i}=\left\{\begin{array}{l}4=\text { strongly agree }(20.51 \%) \\ 3=\text { agree }(50.00 \%) \\ 2=\text { neither agree } / \text { disagree }(19.77 \%) \\ 1=\text { disagree }(7.12 \%) \\ 0=\text { strongly disagree }(2.60 \%)\end{array}\right.\right.$

where $w$ denotes the workplace subscript and $i$ represents the individual subscript, i.e. $w i$ denotes workplace $w$ employing individual $i$. The figures in parenthesis indicate the percentage in each category. ${ }^{5}$ The measure of commitment used in the present study is derived from the six statement scale developed by Lincoln and Kallenberg (1990) to capture Meyer and Allen's construct of affective commitment. The Lincoln-Kallenberg measurement of affective commitment, itself a simplification of the more general Organizational Commitment Questionnaire developed by Mowday et al. (1979), has been used widely in the US and UK (amongst the latter, see Gallie et al. 1998, 2001; and White et al., 2003). The WERS measure of affective commitment, however, uses only three of the six statements designed to capture an employee's identification with the goals and values of the organization in which they are employed and is thus, arguably, a less precise indicator. However, work by Gallie et al. (1998) and Bryson and White (2008) demonstrates that the WERS measure is

\footnotetext{
${ }^{4}$ In one of the early studies in this area, Buchanan (1974) defines organizational commitment as being dedicated to the purposes and values of an organization. The WERS survey question ties in with such a definition.

${ }^{5}$ It should be acknowledged that our analysis is based on self-reported data and the assumption that interpersonal comparisons can be made. The use of such data is becoming increasingly widespread in the economics literature and support for such data can be found in Guest (1990). In an early study, Hogan and Fleishman (1979) support the use of such data citing results from laboratory studies comparing perceived and actual effort exertion in physical activities. They report a highly significant positive correlation between actual metabolic rate and perceived effort in conducting a selection of occupational tasks.
} 
effective in terms of its reliability and predictive power thereby endorsing its construct validity. To be specific, the WERS measure has a high Cronbach alpha measure and a high Kuder-Richardson reliability measure, indicating a high level of reliability. In addition, the WERS commitment measure is found to be positively correlated with measures of job satisfaction and employee well-being (Bryson and White, 2008). Similarly, Green (2008) finds that this measure is characterised by good scale properties with a high Cronbach scale reliability coefficient. Furthermore, Green (p.13) states that the items included in the WERS measure constitute 'the core of the notion of affective commitment'.

Arguably, employees may be unable to distinguish between their commitment and their loyalty to the organization, so following Green (2008), we adopt a hybrid combination of the two questions by generating an additive scale based upon Cronbach's alpha ranging from 0 to 4, where the scale of reliability is 0.77 , which we term the commitment-loyalty index $(C L I)$, our proxy for affective commitment. The distribution across categories 0 to 4 is as follows: $1.27 \% ; 5.15 \% ; 21.54 \% ; 52.31 \%$ and $19.74 \%$ respectively. ${ }^{6}$ The first part of the empirical analysis, presented in Section 4, investigates the determinants of CLI at the employee level. If employee loyalty and commitment towards the workplace influence workplace performance, it is important to ascertain which employee and workplace characteristics are associated with employee commitment and loyalty.

\section{Management Questionnaire}

In Section 5, we conduct workplace level analysis in order to explore the determinants of labor productivity and financial performance. The labor productivity and financial performance measures are derived from the following question included in the Management Questionnaire: I now want to ask you how your workplace is currently performing compared with other establishments in the same industry. How would you assess your workplace's (i)

\footnotetext{
${ }^{6}$ We have also conducted our analysis with categories 0 and 1 amalgamated. Our results are largely unchanged. In addition, we have conducted the analysis without combining the two questions, i.e. analysing them separately. These results, which are discussed below, are available on request.
} 
financial performance and (ii) labour productivity? The management representative was asked to indicate in which of the following categories financial performance $\left(F P_{w}\right)$ and labor productivity $\left(L P_{w}\right.$ ) lay: (i) a lot better than average; (ii) better than average; (iii) about average; (iv) below average or a lot below average. From the responses to these questions, we constructed two four point indices as follows:

$F P_{w}=\left\{\begin{array}{l}3=\text { A lot better than average }(11.66 \%) \\ 2=\text { Better than average }(40.50 \%) \\ 1=\text { About average }(39.11 \%) \\ 0=\text { Below average }(8.73 \%)\end{array} \quad L P_{w}=\left\{\begin{array}{l}3=\text { A lot better than average }(6.91 \%) \\ 2=\text { Better than average }(42.18 \%) \\ 1=\text { About average }(44.90 \%) \\ 0=\text { Below average }(6.01 \%)\end{array}\right.\right.$

where $w$ denotes the workplace subscript and the figures in parenthesis indicate the percentage in each category. It is apparent that both measures of firm performance are subjective and that the response rates also suggest that there is a bias towards the 'above average' categories. Consequently, both performance variables may be subject to measurement error (e.g. see Bertrand and Mullainathan, 2001, and Forth and McNabb, 2008). Insofar as the measurement error is random, this reduces our ability to explain variations in workplace performance. However, if the measurement error correlates with the explanatory variables this will give rise to spurious correlations with the subjective variable. An example of this is common-rater bias where a respondent answers in a positive (negative) way about their workplace in terms of both its work practices and its performance irrespective of the true state of affairs.

In the present context, the significance of this problem will arguably be mitigated due to the fact that data on the explanatory variables of interest are provided by employees whereas the subjective performance measures are provided by management representatives. One would expect there to be less correlation between the measurement error in the latter measures and these explanatory variables. Moreover, evaluations of these subjective measures have indicated that the ordinal properties of the data are unaffected by such bias 
(see Bryson et al., 2005) and that a comparison of these subjective measures and objective profitability and productivity data are weakly equivalent and produce similar results in fairly basic structural models (Forth and McNabb, 2008). ${ }^{7}$

Our set of explanatory variables includes an extensive set of controls for HR practices (see Section 2.1) drawn from the Employee Questionnaire. In order to control for organizational communication, we include four five point indices controlling for the employee's perception of the extent to which the managers at the workplace keep employees informed about: changes to the way the organization is run; changes in staffing; changes in the way work is undertaken; and financial matters including budgets and profits. For each index, 0 denotes very poor, 1 denotes poor, 2 denotes neither good nor poor, 3 denotes good and 4 denotes very good.

Turning to employee involvement, we include three five point indices controlling for the employee's perception of the extent to which managers at the work place: seek the views of employees or employee representatives; respond to suggestions from employees or employee representatives; allow employees or employee representatives to influence financial decisions. These variables are derived from the Employee Questionnaire of WERS. We also include an index of the frequency at which the senior management of the workplace meets with employees, which runs from less than every three months through to daily, and a binary indicator for whether workplace targets are set in conjunction with employees. These two variables are constructed from the Management Questionnaire. A sixteen point index is included, constructed from the Employee Questionnaire, in order to capture the amount of influence employees at the workplace have over: tasks carried out; the pace of work; the

\footnotetext{
${ }^{7}$ In the Financial Performance Questionnaire, continuous measures of workplace financial performance, such as sales turnover and profit per employee, are recorded. However, the sample sizes are greatly reduced (roughly 25 per cent of firms remain) and it is likely that any empirical analysis would be based upon a non random sample. More specifically, Chaplin et al. (2005) state that a relatively high percentage of workplaces declined to take part in this section of the WERS, with a lower average response rate reported for those firms listed on the stock exchange. Consequently, in what follows, we do not analyse these continuous variables of firm performance.
} 
organization of work; order of work; and the times at which work starts and finishes. Higher values of the index indicate a higher level of employee influence. In addition, monitoring and supervision play a prominent role in the organizational commitment literature. Hence, we include an index of the proportion of non-managerial staff with supervisory duties based on the responses to the following question: What proportion of non-managerial employees here have job duties that involve supervising other employees? This is created from the Management Questionnaire in WERS.

Turning to organizational trust, we include four five point indices to control for the extent to which employees are of the opinion that managers in the organization: can be relied upon to keep their promises; are sincere in attempting to understand employees' views; deal with employees honestly; and treat employees fairly. Each of these five point indices are derived from the Employee Questionnaire of WERS, where 0 denotes very poor, 1 denotes poor, 2 denotes neither good nor poor, 3 denotes good and 4 denotes very good.

The organizational communication, employee involvement and trust variables are included in $Z_{w i}$ and are expected to influence $C L I$ as hypothesized in Section 2. Table 2 shows their distributions. Those HR practices associated with information reveal that the majority of individuals think that the organization in which they work has good or very good practices in relation to every day running, changes in staffing etc. Only a relatively small proportion of employees think that the organization is very poor in keeping them informed, between $8 \%$ and $18 \%$ for information regarding how the job is undertaken and changes in finances, respectively. With respect to employee involvement, most employees believe that their employers are good at seeking the views of the workers $(33.7 \%)$ and that managers are good at reacting to employee concerns $(30.37 \%)$, with less than $15 \%$ thinking that managers are very poor at reacting to both types of involvement. Turning to the influence that employees have on firm financial decisions, there are far more responses in the category 
'very poor' at $21.37 \%$. Interestingly, just under $21 \%$ of establishments never have consultation meetings with employees whilst around $22 \%$ of firms meet with their staff at around monthly intervals. Over $50 \%$ of establishments have between $0 \%$ and $19 \%$ of non managerial staff monitoring other employees, and less than $15 \%$ of establishments have over $40 \%$ of non managerial staff having a supervisory role. Focusing on discretion over work tasks, based on a scale of zero to fifteen, where the mean is 9.8 (see Table 1), around $43 \%$ of employees are below the average, which implies they have less discretion over their work. Focusing upon proxies for trust in the organization, around $8 \%$ of employees believe that their employer is very poor at: keeping their promises; sincere in understanding employee views; dealing with employees honestly; and treating employees fairly. However, around $50 \%$ of employees are at the other end of the distribution (i.e. the good or very good categories).

\section{Employee Level Analysis}

\section{Methodology}

Given that employee $C L I$ may influence workplace level performance, which is explored below in Section 5, we focus initially on the determinants of employee CLI. We conduct a generalized ordered probit analysis in order to explore the correlates of CLI allowing for clustering within establishments, which accounts for repeated firm observations. ${ }^{8}$ The generalized ordered probit model for $C L I$ is modeled as follows:

$C L I_{w i}^{*}=\lambda^{\prime} Z_{w i}+\eta_{w i}$

where $C L I_{w i}^{*}$ is a latent variable denoting the unobserved propensity of individual $i$ employed in workplace $w$ to be committed-loyal to workplace $w ; C L I_{w i}$ is the individual's observed level of commitment-loyalty; $Z_{w i}$ is a vector of exogenous characteristics which are expected

\footnotetext{
${ }^{8}$ We adopt the generalised ordered probit approach, which is advantageous in that the cut-off points are allowed to vary between individuals in contrast to the standard ordered probit model.
} 
to influence $C L I_{w i}^{*} ; \lambda$ is the associated vector of coefficients; and $\eta_{w i}$ is the error term, which contains a white noise element and a cluster specific firm effect which specifies that the observations are independent across firms but not necessarily within firms (Cameron and Trivedi, 2005). Our focus in the employee level analysis lies in exploring the role of HR practices in influencing $C L I$.

Additional workplace characteristics that we control for include: a quadratic in workplace size as proxied by the number of employees; the number of dismissals, redundancies and suspensions at the workplace as a percentage of total employment within the workplace, which are expected to have a negative impact on commitment and loyalty. In addition, we control for employee characteristics such as gender and age as well as job characteristics such as: trade union membership; whether the employee works part-time; whether she/he is employed on a permanent contract; whether the individual's performance is subject to regular appraisals; whether the employee is a new recruit at the workplace (i.e. workplace tenure is less than one year); and the individual's wage rate. Summary statistics for the variables used in our empirical analysis are presented in Table 1, and Table 2 reports the distribution of the HR variables and proxies for employee trust in the organization.

\section{Results}

The results of estimating equation (5) are presented in Table 3 where we focus on the marginal effects for each category from the lowest through to the highest level, i.e. categories 0 to 4 , where the two extreme categories denote 'strongly disagree' and 'strongly agree' respectively. $^{9}$

Employee characteristics, specifically age and gender, play the largest roles in terms of the magnitude of the marginal effects across the CLI thresholds. For example, those individuals in the youngest age group are more likely to respond in the lowest $C L I$ category

\footnotetext{
${ }^{9}$ Estimated coefficients in ordered response models have no natural interpretation since the sign of the coefficient only uniquely determines the change in probability at the top and bottom categories of the dependent variable, see Cameron and Trivedi (2005). Hence, we follow convention and focus on the marginal effects.
} 
relative to those individuals aged over 65 by 78 percentage points. Conversely, such individuals are 10 percentage points less likely to respond at the other extreme of the $C L I$ distribution, i.e. the highest category. Part-time employees are less likely to harbour high levels of $C L I$, which is an effect over and above contract type (which is statistically insignificant). Turning to other employee characteristics, there are no effects from being a recent recruit to the firm upon $C L I .{ }^{10}$ Trade union membership is found to lower the probability that an employee will respond in the top category of $C L I$ by around 1 percentage point. This finding is consistent with the literature on unions and absenteeism (Chaudhury and $\mathrm{Ng}, 1992$, and Leigh, 1981; 1985), which shows that union members go absent more often than non-union employees. With respect to the individual's wage, a one per cent increase in the log wage increases the probability that the individual reports the highest category for $C L I$ by 0.04 percentage points.

Turning to the HR practices controls, these are generally individually statistically significant at the highest category of $C L I$ having the largest effects in terms of magnitude as compared to the effect on other categories of $C L I$, see Table 3. For example, those employees who are employed in a workplace which informs their employees over changes in the way that the organization is run are more than 2 percentage points more likely to respond in the highest $C L I$ category. The level of supervision decreases the probability that the individual is in the lowest category of $C L I$, and, at the other end of the $C L I$ index, increases the probability of responding in the highest category, although the magnitude of the effect is small at all points on the $C L I$ distribution. Individuals who are employed in establishments where managers seek employees' views are 1.7 percentage points more likely to respond in the

\footnotetext{
${ }^{10}$ As highlighted by a referee, individuals who have a higher intrinsic propensity to be committed or loyal to their employing firm may select into firms with particular HR practices. Hence, such a distinction might be important in determining whether firms are able to influence $C L I$ by adopting specific HR practices or whether the firm is attracting a more committed pool of labor. Although the absence of information relating to employees over time means that we cannot directly test this, it is interesting to note that the results indicate no statistically significant difference in $C L I$ across new recruits and other employees.
} 
highest category of $C L I$. Similarly, there are positive influences at the top end of the $C L I$ distribution from allowing employees to influence financial decisions, the frequency of consultation meetings with employees and setting targets in consultation with employees, at 0.7, 0.5 and 1.1 percentage points, respectively. The HR practices variables are generally jointly significant both within and across the $C L I$ categories. The proxies for the trust that employees have in the management of the organization have their largest influence at the top end of the distribution. For example, employees who believe that managers can be relied upon to keep promises are approximately 3 percentage points more likely to respond at the top end of the $C L I$ distribution.

In general, focusing on the role of HR practices on the probability of being in the 'strongly agree' category of $C L I$, it is apparent that the marginal effects are largest in magnitude for those HR practices associated with employee involvement and participation. However, as discussed in Section 2.1, there is likely to be potential overlap between the controls in each of the three groups: information and communication; employee involvement and participation; and organizational trust. Hence, in order to explore the robustness of our findings, we obtain an overall composite measure of each of the three groups of variables. The three hybrid combinations are generated on an additive scale based upon Cronbach's alpha, where the scale of reliability is above 0.7 for each measure. Equation (5) is then reestimated conditioning CLI upon the three composite measures, the results of which are shown in Table 4 Panel A. Clearly, at any point on the commitment and loyalty index, the information and communication measure is outweighed in terms of the magnitude of the marginal effects by the involvement and participation measure. Hence, it would appear that HR strategies which target issues other than information and communication may be more advantageous in gaining higher levels of affective commitment. In accordance with the theoretical predictions in Section 2, there is evidence that the employees' trust in the 
organization also has a significant influence across the $C L I$ distribution. In Panels B through to $\mathrm{D}$ of Table 4, equation (5) is re-estimated including each composite index one at a time. This will mitigate any co-linearity between the indexes which may occur by including each composite measure simultaneously. Clearly, the resultant message remains in that generally the influence of involvement and participation outweighs that of information and communication. Having explored the determinants of employee affective commitment to the workplace, the following analysis investigates whether the average level of employee $C L I$ within the workplace influences workplace performance. ${ }^{11}$

\section{Workplace Performance}

\section{Methodology}

The following workplace performance models are estimated where the average level of the employee commitment-loyalty index $(C L I)$ within the workplace, $\overline{C L I}_{w}$, is included in the set of explanatory variables:

$L P_{w}^{*}=\beta^{\prime} X_{w}+\gamma_{1} \overline{C L I}_{w}+v_{1 w}$

$F P_{w}^{*}=\varphi^{\prime} X_{w}+\gamma_{2} \overline{C L I}_{w}+v_{2 w}$

where $L P_{w}^{*}$ and $F P_{w}^{*}$ represent two latent variables denoting the unobserved propensity of workplace $w$ to achieve a certain level of labor productivity and financial performance, respectively; $X_{w}$ is a vector of workplace characteristics expected to influence $L P_{w}^{*}$ and $F P_{w}^{*}$ where $\beta, \varphi, \gamma_{1}$ and $\gamma_{2}$ are the associated vectors of coefficients; and $v_{j w}(j=1,2)$ are random error terms. Thus, the estimated coefficients on $\overline{C L I}_{w}$ indicate the nature of the relationship between average employee $C L I$ within the workplace and the measures of workplace

\footnotetext{
${ }^{11}$ Although our focus is on the determinants of affective commitment, i.e. the utility associated with working for a particular firm, we also explore the effect of including financial considerations in the set of explanatory variables, which serve to influence the budget constraint of the employee and, hence, might reflect factors which would not be expected to influence affective commitment. To be specific, we control for merit or performance pay, profit-sharing and employee share ownership. Our findings indicate that such factors do not influence $C L I$.
} 
performance. $^{12}$ Equations (6) and (7) are estimated using a generalized ordered probit specification over the sample of 1,432 workplaces. The sampling frame used for WERS 2004 was the Inter-Departmental Business Register (IDBR), which is maintained by the Office for National Statistics (ONS). Establishment sampling fractions have been used according to the UK Standard Industrial Classification (SIC) 2003 on the IDBR, with the data being weighted by the probability of selection before the empirical analysis of equations (6) and (7) is undertaken in order to make the sample representative of the designated population, hence reducing non response bias.

The vector of explanatory variables, $X_{w}$, is based on the existing literature and includes: quadratics in workplace size and workplace age; controls for whether the firm is foreign owned or a UK multinational; industrial affiliation; controls for the presence of performance related pay or employee share ownership at the workplace; a dummy indicator for whether there is a recognized trade union at the workplace; a public sector dummy variable $;^{13}$ and the percentages of unskilled, female and ethnic minority employees in the workplace. As a proxy for the relative importance of labor costs within the workplace, we also include a four point index indicating the percentage of the workplace's sales revenue or operating costs, accounted for by wages, salaries and other labor costs such as pensions and insurance. $^{14}$

\footnotetext{
${ }^{12}$ As mentioned in Section 3, we have also investigated incorporating commitment and loyalty simultaneously as two separate measures: only commitment was statistically significant. However, if entered separately, both commitment and loyalty were found to be significantly associated with workplace performance. These results are available from the authors upon request. This suggests that employees may not be able to discern the difference between the two survey questions and, hence, supports the use of a composite measure.

${ }^{13}$ We have also undertaken the empirical analysis excluding the public sector, with the key findings generally unchanged. These results are available on request. However, $20 \%$ of the sample of workplaces are in the public sector, hence excluding such workplaces significantly reduces our sample size. Moreover, substantial variation exists in the mean level of each measure of performance within the public sector where the standard deviations for labor productivity and financial performance are: 0.667 and 0.729 , respectively, (for comparison see Table 1 for the overall sample).

${ }^{14}$ In terms of the labor cost index, a value of zero denotes less than $25 \%$; one denotes $25 \%$ to $50 \%$; two denotes $50 \%$ to $75 \%$; and three denotes $75 \%$ or more. The index indicating the proportion of sales revenue or operating costs accounted for by labor costs enables us to proxy the importance of labor costs relative to the costs of other factor inputs.
} 


\section{Results}

Table 5 presents the results of estimating the relationship between workplace performance and $\overline{C L I}$, with the results of estimating equations (6) and (7) summarised in Panel A. It is apparent from Panel A that, for our sample of 1,432 workplaces, employee $\overline{C L I}$ is positively associated with higher levels of the two measures of workplace performance. ${ }^{15}$ Due to the ordered nature of the labor productivity and financial performance indices, we focus on the marginal effects for each category, lowest through to highest, i.e. categories 0 to 3 , where the two extreme categories denote 'below average' and 'a lot above average' respectively.

With respect to labor productivity, $L P_{w}$, shown in the first column of Table 5 , the marginal effects presented in Panel A indicate that $\overline{C L I}$ is associated with a decrease in the probability that workplace labor productivity is 'below average' by 10 percentage points evaluated at the sample mean. Conversely, $\overline{C L I}$ is also associated with an increase in the probability that labor productivity is 'a lot above average' by 9 percentage points evaluated at the sample mean. ${ }^{16}$ We replicate the above analysis focusing on the alternative measure of workplace performance, financial performance $\left(F P_{w}\right)$, in the second column of Table 5 . The results are consistent with those found for labor productivity in that higher levels of $\overline{C L I}$ are associated with a decrease in the probability of financial performance being 'below average'. Evaluated at the sample mean, the largest effect of $\overline{C L I}$ serves to increase the probability that workplace financial performance is 'above average' by 16 percentage points.

It is possible that for certain occupations employees may have more discretion over their effort/productivity. Consequently, the influence of average CLI upon firm labor

\footnotetext{
${ }^{15}$ For brevity, we omit the full results of estimating the models of workplace performance. In accordance with the existing literature, our findings suggest that workplace size, whether the workplace has performance related pay or employee share ownership, all increase the probability of having the highest level of financial performance. Conversely, workplace age, a high proportion of labor costs relative to sales revenue and the proportion of ethnic employees decrease the probability of attaining high workplace performance. These results are available from the authors on request.

${ }_{16}$ These calculations are based on the mean sample characteristics of workplaces. For example, the 10 percentage point effect is calculated by multiplying the marginal effect by the mean of average CLI.
} 
productivity or financial performance may be somewhat different across occupations. To investigate this possibility we interact $\overline{C L I}$ with binary indicators representing the largest occupation group within the firm (based upon the UK 2000 Social Occupational Classification): professional; associate professional and technical; administrative and secretarial; skilled trade; personal service; sales and customer service; process, plant and machine operatives; and elementary occupations. The results of this analysis are presented in Table 5 Panel B where the influence of $\overline{C L I}$ at each point of the labor productivity index and the financial performance index varies by occupation, in particular at the two extremes of the workplace performance measures. For example, at the extremes of both workplace performance measures, $\overline{C L I}$ generally has a larger effect in firms where the principal occupational group is professional or associate professional, which are arguably occupations associated with a greater degree of autonomy and discretion over tasks performed.

To summarise, our workplace results suggest that $C L I$ is positively related to higher levels of labor productivity and financial performance at the workplace. Moreover, the magnitudes of the estimated effects suggest that engendering worker attachment to the organization is potentially an important conduit for improved workplace performance, along the lines discussed in Section 2. It should be noted that workers who are more committed to their job or feel a greater obligation to their employer may be more likely to remain with a failing firm. This would generate a negative correlation between $C L I$ and firm performance hence leading to an underestimate of the impact of $C L I$ upon labor productivity and financial performance. ${ }^{17,18}$

\footnotetext{
${ }^{17}$ Workplaces which indicated that it was not possible to make comparisons about labor productivity or financial performance or that the relevant data were not available were excluded from our sample (approximately 32\%). We have experimented with recoding the missing values in the dependent variable by including these workplaces in the 'about average' category, which increases the sample size to over 2,100. Testing the difference in the estimated coefficients between the estimates reported in Table 2 and those based upon the larger sample size reveals no significant difference in the estimated relationship between $C L I$ and performance at the $1 \%$ level. Similarly, for the employee level results, the sample size of 17,208 employees is governed by the number of workplaces we analyse and, in addition, whether employees respond to the
} 


\section{Conclusion}

In this paper we have analysed matched employer-employee data in order to explore the influence of employee commitment and loyalty on workplace performance. Our empirical findings suggest that employee commitment and loyalty are positively associated with higher levels of workplace performance. Arguably, it is thus in an establishment's interest to foster such attachments as we explain through a theoretical justification. Hence, our empirical analysis highlights a potential avenue for productivity and financial gains at the establishment level, which has been somewhat neglected in the economics literature. Moreover, our employee level analysis of the determinants of employee attitudes suggests not only a role for worker characteristics, but also for workplace characteristics, in particular human resource practices and engendering employee trust in the organization, in influencing such attachments. Such findings suggest that establishments may be able to exert some control over the loyalty and commitment of its workforce, which, in turn, may enhance establishment performance. One interesting area of future research entails exploring how the interaction between different types of employee commitment may influence firm performance, as well as how human resources practices influence different types of commitment.

\section{References}

AGHION, P. AND TIROLE, J. (1997) 'Formal and Real Authority in Organizations', Journal of Political Economy, 105(1), 1-29.

AKERLOF, G. (1982) 'Labor Contracts as a Partial Gift Exchange', Quarterly Journal of Economics, 97, 543- 69.

\footnotetext{
commitment and loyalty questions, i.e. the dependent variable. We have experimented with recoding missing values in $C L I$ in the employee level data to the 'neither agree/disagree' category, yielding a sample size over 21,100 employees. The results reported in Table 1 are largely unaffected. Indeed, testing the difference between the estimated coefficients from equation (1) estimated across 17,208 employees and that for 21,100 employees, we find no significant difference at the $5 \%$ level.

${ }^{18}$ We have explored the robustness of the estimated relationship between $C L I$ and workplace performance, by investigating the possibility of reverse causality between $C L I$ and workplace performance, i.e. the potential for high performance organizations to engender greater levels of CLI. To consider this we make use of the panel element of WERS, which enables us to analyze the change in workplace financial performance $(\Delta P)$ over the period 1998 to 2004 and how this is influenced by average $C L I$ in 1998 , i.e. $\Delta P_{w, 2004}=g\left(\overline{C L I}_{w, 1998}\right)$, arguably enabling a stronger causal interpretation. The results, available from the authors upon request, reveal a positive relationship which is consistent with the above findings.
} 
AKERLOF, G AND YELLEN, J. (1990) 'The Fair Wage-Effort Hypothesis and Unemployment', Quarterly Journal of Economics, 105, 255-83.

AKERLOF, G. A. AND KRANTON, R. E. (2000) 'Economics and Identity', Quarterly Journal of Economics, 105(2), 255-83.

AKERLOF, G. A. AND KRANTON, R. E. (2005) 'Identity and the Economics of Organizations', Journal of Economic Perspectives, 19(1), 9-32.

ANDERSON, C. M. AND MARTIN, M. M. (1995) 'Why Employees Speak to Co-workers and Bosses: Motives, Gender, and Organizational Satisfaction' Journal of Business Communication, 32, 249-65.

ASHFORD, S. J., LEE, C., AND BOBKO, P. (1989). 'Content, causes, and consequences of job insecurity: A theory-based measure and substantive test', The Academy of Management Journal, 32, 803-29.

ATHEY, S. AND ROBERTS, J. (2001) 'Organizational Design: Decision Rights and Incentive Contracts', American Economic Review, 91(2), 200-205.

BERTRAND, M. AND MUlLAinATHAN, S. (2001) 'Do People Mean What They Say? Implications for Subjective Survey Data', American Economic Review, 91, 67-72.

BEWLEY, H., BRYSON, A., FORTH, J. AND STOKES, L. (2010). Review of the Workplace Employment Relations Survey (WERS) 2004 - Survey of Employees Questionnaire, NIESR.

BRUNETTO, Y. AND FARR-WHARTON, R. (2004) 'Does the Talk Affect Your Decision to Walk', Management Decision, 42, 579-600.

BRYSON, A., J. FORTH and KIRBY, S. (2005) 'High Involvement Management Practices, Trade Union Representation and Workplace Performance in Britain', Scottish Journal of Political Economy, 52(3), 451-491.

BRYSON, A., J. and WHITE, M. (2008) 'Organizational Commitment: Do Workplace Practices Matter?' CEP Discussion Paper No. 0881.

BUCHANAN, B. (1974) 'Building Organizational Commitment: The Socialization of Managers in Work Organizations', Administrative Science Quarterly, 19, 533-46.

CAMERON, A. AND TRIVEDI, P. (2005) Microeconometrics: Methods and Applications. Cambridge University Press.

CASSAR, V. (1999) 'Can Leader Direction and Employee Participation Co-Exist? Investigating Interaction Effects Between Participation and Favourable Work-Related Attitudes Among Maltese Middle-Managers', Journal of Managerial Psychology, 14, 57-68.

CHAPLIN, J. MANGLA, J., PURDON, S. AND AIREY, C. (2005) 'The Workplace Employment Relations (WERS) 2004 Technical Report (Cross-Section and Panel Surveys)', Department of Trade and Industry, November 2005.

CHAUDHURY, M. and NG, I. (1992) 'Absenteeism Predictors: Least Squares, Rank Regression and Model Selection Results', Canadian Journal of Economics, 25, 61535.

COTTON, J. L., VOLLRATH, D. A., FROGGATT, K. G., LENGNICK-HALL, M. C. AND JENNINGS, E. R. (1998). 'Employee participation: Diverse forms and different outcomes', Academy of Management Review, 13, 8-22. 
FORTH, J. AND MCNABB, R. (2008) 'Workplace Performance: A Comparison of Subjective and Objective Measures in the 2004 Workplace Employment Relations Survey', Industrial Relations, 39, 104-23.

GALliE, D., WHITE, M., CHENG, Y. AND TOMLINSON, M. (1998) Restructuring the Employment Relationship. Oxford University Press.

GALliE, D., FELSTEAD, A. AND GREEN, F. (2001) 'Employer Policies and Organisational Commitment in Britain 1992-1997', Journal of Management Studies, 38, 1081-102.

GILBERT, J. A. AND TANG, T, L. (1998) 'An examination of organizational trust antecedents', Public Personnel Management, 27(3), 321-36.

GORIS, J.R., VAUGHT, B.C. AND PETTIT, J.D. (2000) 'Effects of communication direction on job performance and satisfaction: A moderated regression analysis', Journal of Business Communication, 37(4), 348-68.

GREEN, F. (2008) 'Leeway for the Loyal: A Model of Employee Discretion', British Journal of Industrial Relations, 46(1), 1-32.

GRILICHES, Z. and REGEV, H. (1995) 'Firm Productivity in Israeli Industry: 1979-1988', Journal of Econometrics, 65(1), 175-203.

GRIFFITH, R. and SIMPSON, H. (2004) 'Characteristics of Foreign-Owned Firms in British Manufacturing', in Creating A Premier League Economy, R. Blundell, D., Card, and R., Freeman (Editors), Chicago: Chicago University Press.

GUEST, D. E. (1990) 'Have British Workers Been Working Harder in Thatcher's Britain? A Re-Consideration of the Concept of Effort', British Journal of Industrial Relations, 28, 293-312.

HARTMANN, C. AND BAMBACAS, M. (2000) 'Organisational Commitment: A MultiMethod Scale Analysis and Test of Effects', International Journal of Organisational Analysis, 8(91), 89-108.

HASKINS, W (1996) 'Freedom of Speech: Construct for Creating a Culture Which Empowers Organizational Members' Journal of Business Communication, 33, 85-97.

HOGAN, J. C. and FLEISHMAN, E. A. (1979) 'An Index of the Physical Effort Required in Human Task Performance', Journal of Applied Psychology, 64, 197-204.

KARIA, N. AND AHMAD, Z. A. (2000) 'Quality practices that pay: Empowerment and teamwork', Malaysian Management Review, 35(2), 66-76.

LAZEAR, E. P. (2000) 'Performance Pay and Productivity', American Economic Review, 90(5), 1346-61.

LEIGH, J. P. (1981) 'The Effects of Union Membership on Absence from Work due to Illness', Journal of Labor Research, 2, 329-36.

LEIGH, J. P. (1985) 'The Effects of Unemployment and the Business Cycle on Absenteeism', Journal of Economics and Business, 37, 159-70.

LinCOln, J. R. AND KAlleBERG, A. L. (1990) Culture, Control and Commitment. Cambridge University Press.

MACHIN, S. AND STEWART, M. (1990) 'Unions and Financial Performance of British Private Sector Establishments', Journal of Applied Econometrics, 5, 327-50.

MAYFIELD, J. AND MAYFIELD, M. (2002) 'Leader communication strategies: Critical paths to improving employee commitment', American Business Review, 20(2), 89-94. 
McNABB, R. AND WHITFIELD, K. (1998) 'The Impact of Financial Participation and Employee Involvement on Financial Performance', Scottish Journal of Political Economy, 45, 171-87.

MEYER, J. P. AND ALLEN, N. J. (1991) 'A Three-Component Conceptualization of Organizational Commitment', Human Resource Management Review, 1, 61-89.

MEYER, J. P., ALLEN, N. J. AND SMITH, C. A. (1993) 'Commitment to Organizations and Occupations: Extension and Test of a Three Component Conceptualization', Journal of Applied Psychology, 78, 538-51.

MEYER, J. P., STANLEY, D. J., HERSCOVITCH, L. AND TOPOLNYTSKY, L. (2002) 'Affective, Continuance, and Normative Commitment to the Organization: A MetaAnalysis of Antecedents, Correlates, and Consequences', Journal of Vocational Behavior, 61, 20-52.

MISHRA, J. AND MORRISSEY, M.A. (1990) 'Trust in employee/employer relationships: A survey of West Michigan managers', Public Personnel Management, 19(4), 443-463.

MOWDAY, R. T., STEERS, R. M. AND PORTER, L. W. (1979) 'The Measurement of Organizational Commitment', Journal of Vocational Behavior, 14, 224-47.

MUNDAY, M., PEEL, M. AND TAYLOR, K. (2003) 'The Performance of the ForeignOwned Sector of UK Manufacturing: Some Evidence and Implications for UK Inward Investment Policy', Fiscal Studies, 24, 501-21.

OOI, K. B, SAFA, M. S AND ARUMUGAM, V. (2006) 'TQM Practices and Affective Commitment: A Case of Malaysian Semiconductor Packaging Organizations', International Journal of Management and Entrepreneurship, 2(1), 37-55.

OULTON, N. (1998) 'Competition and the Dispersion of Labour Productivity amongst UK Companies', Oxford Economic Papers, 50(1), 23-38.

PODSAKOFF, P.M., MACKENZIE, S.B, AND BOMMER, W.H. (1996) 'Transformational Leader Behaviors and Substitutes for Leadership as Determinants of Employee Satisfaction, Commitment, Trust, and Organizational Citizenship Behaviors', Journal of Management, 22, 259-98.

STUART, H. (1999) 'Towards a Definite Model of the Corporate Identity Management Process', Corporate Communication, 4, 200-7.

WHITE, M., Hill, S., McGOVERN, P., MILlS, C. AND SMEATON, D. (2003) 'High Performance Management Practices, Working Hours and Work-Life Balance', British Journal of Industrial Relations, 41, 175-96. 


\begin{tabular}{|c|c|c|c|c|}
\hline & MEAN & STD DEV & MIN & MAX \\
\hline \multicolumn{5}{|l|}{ WORKPLACE LEVEL ANALYSIS } \\
\hline Financial Performance & 1.5509 & 0.8097 & 0 & 3 \\
\hline Labor Productivity & 1.5001 & 0.7132 & 0 & 3 \\
\hline Average Commitment Loyalty Index & 2.9581 & 0.4680 & 0 & 4 \\
\hline OBSERVATIONS & \multicolumn{4}{|c|}{1,432} \\
\hline EMPLOYEE LEVEL ANALYSIS & & & & \\
\hline Male & 0.4730 & 0.4993 & 0 & 1 \\
\hline Part time & 0.2086 & 0.4064 & 0 & 1 \\
\hline Age 16-19 & 0.0319 & 0.1760 & 0 & 1 \\
\hline Age $20-29$ & 0.1819 & 0.3858 & 0 & 1 \\
\hline Age 30-39 & 0.2533 & 0.4349 & 0 & 1 \\
\hline Age $40-49$ & 0.2681 & 0.4430 & 0 & 1 \\
\hline Age $50-59$ & 0.2194 & 0.4139 & 0 & 1 \\
\hline Age $60-64$ & 0.0367 & 0.1879 & 0 & 1 \\
\hline Tenure $\leq 1$ year & 0.1552 & 0.3621 & 0 & 1 \\
\hline Permanent contract & 0.9237 & 0.2655 & 0 & 1 \\
\hline Trade union member & 0.3712 & 0.4831 & 0 & 1 \\
\hline Regular performance appraisal & 0.7089 & 0.4543 & 0 & 1 \\
\hline Log wage & 10.9876 & 16.9769 & 0.44643 & 871 \\
\hline \multicolumn{5}{|l|}{ Information and Communication } \\
\hline Informed over way organization is run & 2.1391 & 1.1675 & 0 & 4 \\
\hline Informed over changes in staffing & 2.2759 & 1.1611 & 0 & 4 \\
\hline Informed over changes in way job undertaken & 1.9432 & 1.0762 & 0 & 4 \\
\hline Informed over changes in finances: budget \& profit & 9.7959 & 1.2293 & 0 & 4 \\
\hline \multicolumn{5}{|l|}{ Employee Involvement and Participation } \\
\hline Managers seek employee views & 2.1523 & 1.1746 & 0 & 4 \\
\hline Managers respond to employee concerns & 2.0421 & 1.1644 & 0 & 4 \\
\hline Employees influence financial decisions & 1.6965 & 1.1854 & 0 & 4 \\
\hline Frequency of employee consultation meetings & 2.1002 & 1.7025 & 0 & 6 \\
\hline Targets set in consultation with employees & 0.3513 & 0.4774 & 0 & 1 \\
\hline Discretion over work: e.g. tasks, pace, organization & 9.7959 & 3.7616 & 0 & 15 \\
\hline Index of $\%$ supervisors & 1.6005 & 1.0799 & 0 & 6 \\
\hline \multicolumn{5}{|l|}{ Organizational Trust } \\
\hline Employers can be relied upon to keep promises & 2.1751 & 1.1060 & 0 & 4 \\
\hline Employers are sincere & 2.3028 & 1.0095 & 0 & 4 \\
\hline Employers deal with employees honestly & 2.3430 & 1.0957 & 0 & 4 \\
\hline Employers deal with employees fairly & 2.3643 & 1.1258 & 0 & 4 \\
\hline \multicolumn{5}{|l|}{ Other Workplace Controls } \\
\hline Log workplace size & 4.8366 & 1.5782 & 1.6094 & 8.7979 \\
\hline Log workplace size squared & 25.8832 & 16.1884 & 2.5903 & 77.4022 \\
\hline Percentage of dismissals & 1.1291 & 3.0991 & 0 & 100 \\
\hline Percentage of redundancies & 2.0706 & 8.7046 & 0 & 100 \\
\hline Percentage of suspensions & 4.2833 & 4.9488 & 0 & 100 \\
\hline OBSERVATIONS & \multicolumn{4}{|c|}{17,208} \\
\hline
\end{tabular}


TABLE 2: DISTRIBUTION OF 'INFORMATION AND COMMUNICATION', 'EMPLOYEE INVOLVEMENT AND PARTICIPATION' AND 'ORGANIZATIONAL TRUST'

\section{0}

Information and Communication

\section{Informed over way organization is run ${ }^{a}$}

Informed over changes in staffing ${ }^{a}$

Informed over changes in way job undertaken ${ }^{a}$

Informed over changes in finances: budget $\&$ profit $^{a}$

\section{Employee Involvement and Participation}

Managers seek employee views ${ }^{a}$

Managers respond to employee concerns ${ }^{a}$

Employees influence financial decisions ${ }^{a}$

Frequency of employee consultation meetings ${ }^{b}$

Targets set in consultation with employees ${ }^{c}$

Discretion over work: e.g. tasks, pace, organization ${ }^{d}$

Index of $\%$ supervisors ${ }^{e}$

\section{Organizational Trust}

Employers can be relied upon to keep their promises ${ }^{a}$

Employers are sincere in understanding employee views ${ }^{a}$

Employers deal with employees honestly ${ }^{a}$

Employers treat employees fairly ${ }^{a}$

$9.48 \% \quad 17.06 \%$

$10.61 \%$

$19.30 \%$

$7.98 \%$

$17.59 \%$

$13.83 \%$

$16.83 \%$

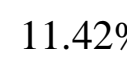

\section{$13.05 \%$}

$17.38 \%$

$17.76 \%$

$21.37 \%$

$20.16 \%$

$20.95 \%$

$20.70 \%$

$64.87 \%$

$35.13 \%$

$42.47 \%$

$10.62 \%$

$10.01 \%$
2

$23.17 \%$

$25.97 \%$

$30.91 \%$

$28.22 \%$

$37.51 \%$

$12.78 \%$

$10.30 \%$

$37.14 \%$

$10.13 \%$

$28.41 \%$

$8.96 \%$

$26.62 \% \quad 33.70 \%$

$10.88 \%$

$29.97 \%$

$30.37 \%$

$8.85 \%$

$31.66 \%$

$21.06 \%$

$5.75 \%$

$21.73 \%$

$18.12 \%$

$4.32 \%$

$10.84 \%$

$3.34 \%$

$-$

$9.16 \%$

$10.59 \%$

$-$

$-$

-

$32.12 \%$

$8.64 \%$

$3.74 \%$

$8.07 \%$

$11.01 \%$

$\begin{array}{lllll}8.86 \% & 18.42 \% & 27.99 \% & 35.80 \% & 8.93 \% \\ 7.63 \% & 16.21 \% & 24.72 \% & 41.14 \% & 10.30 \% \\ 7.63 \% & 14.29 \% & 25.79 \% & 40.71 \% & 11.57 \% \\ 8.43 \% & 13.39 \% & 24.61 \% & 40.46 \% & 13.11 \%\end{array}$

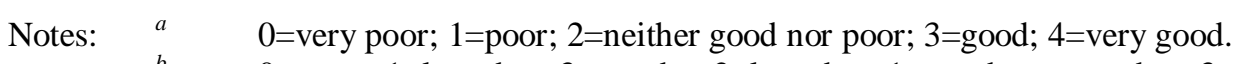

$0=$ none; $1=$ less than 3 months; $2=$ less than 1 month greater than 3 months; $3=$ less than a fortnight greater than 1 month; $4=$ less than weekly greater than a fortnight; $5=$ less than daily greater than once a week; $6=$ daily

c $0=$ no, $1=$ yes

Discretion amalgamation of responses to: influence over tasks $[0=$ none, $1=$ a little, $2=$ some, $3=a$ lot]; influence over pace of work $[0=$ none, $1=a$ little, $2=$ some, $3=\mathrm{a}$ lot]; influence over way work executed $[0=$ none, $1=\mathrm{a}$ little, $2=$ some, $3=\mathrm{a}$ lot]; influence over order tasks performed $[0=$ none, $1=\mathrm{a}$ little, $2=\mathrm{some}, 3=\mathrm{a}$ lot $]$; and influence over start and finish time $[0=$ none, $1=\mathrm{a}$ little, $2=$ some, $3=\mathrm{a}$ lot $]$. Range shown in table $0=0-9 ; 1=10 ; 2=11 ; 3=12 ; 4=13 ; 5=14 ; 6=15$. $0=$ none; $1=1-19 \% ; 2=20-39 \% ; 3=40-59 \% ; 4=60-79 \% ; 5=80-99 \% ; 6=100 \%$. 


\begin{tabular}{|c|c|c|c|c|c|c|c|c|c|c|}
\hline & \multicolumn{2}{|c|}{$C L I=0$} & \multicolumn{2}{|c|}{$C L I=1$} & \multicolumn{2}{|c|}{$C L I=2$} & \multicolumn{2}{|c|}{$C L I=3$} & \multicolumn{2}{|c|}{$C L I=4$} \\
\hline & M.E. & $\underline{T S T A T}$ & M.E. & $\underline{T S T A T}$ & M.E. & $\underline{T S T A T}$ & M.E. & $\underline{T S T A T}$ & M.E. & $\underline{T S T A T}$ \\
\hline Information and Communication & & & & & & & & & & \\
\hline Informed over way organization is run & -0.00023 & $(1.15)$ & -0.00349 & $(2.42)$ & -0.01405 & $(2.72)$ & -0.00427 & $(0.67)$ & 0.02204 & $(4.62)$ \\
\hline Informed over changes in staffing & -0.00007 & $(0.32)$ & 0.00002 & $(0.02)$ & 0.00037 & $(0.07)$ & 0.00386 & $(0.63)$ & -0.00418 & $(1.01)$ \\
\hline Informed over changes in way job undertaken & 0.00005 & $(0.24)$ & -0.00301 & $(2.00)$ & -0.02061 & $(4.18)$ & 0.01844 & $(2.93)$ & 0.00514 & $(1.07)$ \\
\hline $\begin{array}{c}\text { Informed over changes in finances: budget \& profit } \\
\text { Employee Involvement and Participation }\end{array}$ & -0.00043 & $(2.53)$ & -0.00358 & $(3.05)$ & -0.00549 & $(1.41)$ & 0.00553 & $(1.22)$ & 0.00398 & $(1.30)$ \\
\hline Managers seek employee views & -0.00003 & $(0.14)$ & -0.00281 & $(1.88)$ & -0.01506 & $(3.03)$ & 0.00085 & $(0.14)$ & 0.01705 & $(3.61)$ \\
\hline Managers respond to employee concerns & -0.00057 & $(1.88)$ & -0.00344 & $(2.26)$ & -0.01852 & $(3.46)$ & 0.01400 & $(2.15)$ & 0.00852 & $(1.82)$ \\
\hline Employees influence financial decisions & -0.00016 & $(0.60)$ & -0.00266 & $(1.81)$ & -0.01027 & $(2.30)$ & 0.00597 & $(1.16)$ & 0.00712 & $(2.09)$ \\
\hline Frequency of employee consultation meetings & -0.00015 & $(1.56)$ & -0.00020 & $(0.31)$ & -0.00607 & $(2.60)$ & 0.00145 & $(0.57)$ & 0.00497 & $(2.43)$ \\
\hline Targets set in consultation with employees & -0.00033 & $(1.19)$ & -0.00384 & $(1.73)$ & -0.02479 & $(3.02)$ & 0.01745 & $(1.96)$ & 0.01151 & $(1.62)$ \\
\hline Discretion over work: e.g. tasks, pace, organization & -0.00015 & $(2.86)$ & -0.00167 & $(6.12)$ & -0.00904 & $(9.32)$ & 0.00077 & $(0.64)$ & 0.01008 & $(10.77)$ \\
\hline $\begin{array}{l}\text { Index of \% supervisors } \\
\text { Organizational Trust }\end{array}$ & -0.00015 & $(1.15)$ & -0.00179 & $(1.74)$ & -0.00373 & $(1.00)$ & -0.00193 & $(0.48)$ & 0.00761 & $(2.51)$ \\
\hline Employers can be relied upon to keep promises & -0.00087 & $(3.08)$ & -0.00748 & $(5.25)$ & -0.03205 & $(6.30)$ & 0.01228 & $(2.01)$ & 0.02813 & $(6.19)$ \\
\hline Employers are sincere in understanding employee views & -0.00023 & $(1.15)$ & -0.00196 & $(1.26)$ & -0.03241 & $(6.04)$ & 0.00945 & $(1.37)$ & 0.02515 & $(4.51)$ \\
\hline Employers deal with employees honestly & -0.00037 & $(1.63)$ & -0.00624 & $(4.23)$ & -0.00959 & $(1.80)$ & 0.00049 & $(0.07)$ & 0.01572 & $(2.95)$ \\
\hline $\begin{array}{l}\text { Employers treat employees fairly } \\
\text { Employee and workplace characteristics }\end{array}$ & -0.00078 & $(2.98)$ & -0.01014 & $(7.94)$ & -0.03458 & $(7.39)$ & 0.02231 & $(3.63)$ & 0.02319 & $(4.93)$ \\
\hline Male & 0.00080 & $(1.93)$ & 0.00744 & $(3.63)$ & 0.01988 & $(2.63)$ & -0.02975 & $(3.40)$ & 0.00163 & $(0.26)$ \\
\hline Part time & 0.00022 & $(0.50)$ & -0.00084 & $(0.32)$ & 0.01169 & $(1.19)$ & 0.01702 & $(1.52)$ & -0.02809 & $(3.98)$ \\
\hline Age 16-19 & 0.77872 & $(13.42)$ & -0.70476 & $(9.01)$ & 0.24279 & $(3.66)$ & -0.21856 & $(3.34)$ & -0.09819 & $(6.64)$ \\
\hline Age $20-29$ & 0.55242 & $(10.02)$ & -0.48295 & $(6.69)$ & 0.19313 & $(3.39)$ & -0.18599 & $(3.13)$ & -0.07661 & $(3.87)$ \\
\hline Age 30-39 & 0.36730 & (6.95) & -0.32908 & $(5.37)$ & 0.16598 & $(3.21)$ & -0.16387 & $(2.84)$ & -0.04034 & $(1.69)$ \\
\hline Age $40-49$ & 0.40434 & $(7.76)$ & -0.36612 & $(6.09)$ & 0.12869 & $(2.56)$ & -0.13897 & $(2.44)$ & -0.02794 & $(1.12)$ \\
\hline Age $50-59$ & 0.41944 & $(7.55)$ & -0.38605 & $(6.06)$ & 0.12359 & $(2.41)$ & -0.13812 & $(2.42)$ & -0.01887 & $(0.75)$ \\
\hline Age 60-64 & 0.69446 & $(8.83)$ & -0.65642 & $(7.35)$ & 0.03838 & $(0.70)$ & -0.08279 & $(1.35)$ & 0.00638 & $(0.21)$ \\
\hline Tenure $\leq 1$ year & 0.00112 & $(1.51)$ & 0.00193 & $(0.60)$ & -0.00402 & $(0.39)$ & 0.00040 & $(0.03)$ & 0.00058 & $(0.07)$ \\
\hline Permanent contract & -0.00005 & $(0.10)$ & -0.00156 & $(0.41)$ & -0.00219 & $(0.16)$ & -0.00601 & $(0.36)$ & 0.00981 & $(0.94)$ \\
\hline Trade union member & 0.00008 & $(0.29)$ & 0.00427 & $(1.89)$ & 0.00054 & $(0.07)$ & 0.00842 & $(1.24)$ & -0.01331 & $(2.54)$ \\
\hline Regular performance appraisal & 0.00009 & $(0.33)$ & -0.00110 & $(0.47)$ & 0.00596 & $(0.69)$ & 0.00246 & $(0.27)$ & -0.00741 & $(0.98)$ \\
\hline Log wage & 0.00004 & $(1.06)$ & 0.00005 & $(1.53)$ & -0.00036 & $(1.97)$ & -0.00011 & $(0.44)$ & 0.00040 & $(2.36)$ \\
\hline Log workplace size & -0.00079 & $(1.52)$ & -0.00696 & $(1.80)$ & -0.02165 & $(1.62)$ & 0.03213 & $(2.16)$ & -0.00274 & $(0.23)$ \\
\hline Log workplace size squared & 0.00007 & $(1.42)$ & 0.00063 & $(1.78)$ & 0.00171 & $(1.33)$ & -0.00224 & $(1.54)$ & -0.00017 & $(0.15)$ \\
\hline Percentage of dismissals & -0.00004 & $(0.81)$ & -0.00003 & $(0.10)$ & 0.00074 & $(0.66)$ & 0.00052 & $(0.48)$ & -0.00118 & $(1.68)$ \\
\hline Percentage of redundancies & 0.00002 & $(1.32)$ & 0.00046 & $(3.26)$ & 0.00110 & $(2.12)$ & -0.00098 & $(2.24)$ & -0.00059 & $(1.54)$ \\
\hline Percentage of suspensions & -0.0025 & $(0.80)$ & 0.00015 & $(0.06)$ & -0.00984 & $(1.04)$ & 0.00944 & $(0.95)$ & 0.00049 & $(0.06)$ \\
\hline OBSERVATIONS, Chi Squared & & & & 17,20 & $6,279$. & $p=[0.00$ & & & & \\
\hline
\end{tabular}


TABLE 4: THE DETERMINANTS OF EMPLOYEE COMMITMENT AND LOYALTY: EMPLOYEE LEVEL ANALYSIS

\begin{tabular}{|c|c|c|c|c|c|c|c|c|c|c|}
\hline \multirow[t]{2}{*}{ PANEL A: ALL COMPOSITE MEASURES } & \multicolumn{2}{|c|}{$C L I=0$} & \multicolumn{2}{|c|}{$C L I=1$} & \multicolumn{2}{|c|}{$C L I=2$} & \multicolumn{2}{|c|}{$C L I=3$} & \multicolumn{2}{|c|}{$C L I=4$} \\
\hline & M.E. & $\underline{T S T A T}$ & M.E. & $\underline{T S T A T}$ & M.E. & $\underline{T S T A T}$ & M.E. & $\underline{\text { TSTAT }}$ & M.E. & $\underline{T S T A T}$ \\
\hline Information and Communication & -0.00116 & $(4.05)$ & -0.01232 & $(8.55)$ & -0.04898 & $(11.36)$ & 0.01969 & $(5.30)$ & 0.03359 & $(8.30)$ \\
\hline Employee Involvement and Participation & -0.00136 & (4.14) & -0.01278 & (9.18) & -0.06535 & $(13.98)$ & 0.02887 & (3.49) & 0.05979 & $(14.42)$ \\
\hline \multicolumn{11}{|l|}{ Employee and workplace characteristics } \\
\hline Male & 0.00102 & $(2.10)$ & 0.00744 & (3.47) & 0.01957 & $(2.60)$ & -0.03053 & $(3.52)$ & 0.00249 & $(0.39)$ \\
\hline Part time & 0.00028 & $(0.50)$ & -0.00144 & $(0.51)$ & 0.00963 & $(0.98)$ & 0.02097 & $(1.88)$ & -0.02945 & $(4.15)$ \\
\hline Age $16-19$ & 0.86137 & $(20.31)$ & -0.77546 & $(10.90)$ & 0.24197 & $(3.60)$ & -0.22292 & $(3.48)$ & -0.10496 & $(7.39)$ \\
\hline Age $20-29$ & 0.66546 & $(13.72)$ & -0.58449 & $(8.49)$ & 0.19619 & $(3.41)$ & -0.19003 & $(3.24)$ & -0.08714 & $(4.45)$ \\
\hline Age 30-39 & 0.47301 & $(8.95)$ & -0.42771 & $(6.86)$ & 0.17323 & $(3.35)$ & -0.16731 & (2.93) & -0.05123 & $(2.14)$ \\
\hline Age $40-49$ & 0.50816 & $(9.98)$ & -0.46405 & $(7.75)$ & 0.13539 & $(2.70)$ & -0.14128 & $(2.50)$ & -0.03822 & $(1.52)$ \\
\hline Age $50-59$ & 0.52230 & $(9.67)$ & -0.48341 & $(7.64)$ & 0.13184 & $(2.56)$ & -0.14194 & $(2.49)$ & -0.02879 & $(1.15)$ \\
\hline Age $60-64$ & 0.78590 & $(12.65)$ & -0.74282 & $(9.71)$ & 0.04205 & $(0.76)$ & -0.08322 & $(1.36)$ & -0.00192 & $(0.06)$ \\
\hline Tenure $\leq 1$ year & 0.00122 & $(1.42)$ & 0.00058 & $(0.18)$ & -0.00859 & $(0.84)$ & 0.00335 & $(0.28)$ & 0.00344 & $(0.43)$ \\
\hline Permanent contract & -0.00016 & $(0.24)$ & -0.00248 & $(0.61)$ & -0.00202 & $(0.15)$ & -0.00416 & $(0.25)$ & 0.00881 & $(0.83)$ \\
\hline Trade union member & 0.00006 & $(0.15)$ & 0.00491 & $(2.02)$ & -0.00009 & $(0.01)$ & -0.01138 & $(1.32)$ & 0.00651 & $(0.96)$ \\
\hline Regular performance appraisal & 0.00006 & $(0.16)$ & -0.00155 & $(0.63)$ & 0.00333 & $(0.39)$ & 0.00553 & $(0.60)$ & -0.00738 & $(0.98)$ \\
\hline Log wage & 0.00005 & $(1.22)$ & 0.00006 & $(1.43)$ & -0.00036 & $(1.95)$ & -0.00013 & $(0.56)$ & 0.00043 & $(2.52)$ \\
\hline Log workplace size & -0.00097 & $(1.48)$ & -0.00670 & $(1.63)$ & -0.01759 & $(1.34)$ & 0.02972 & $(2.01)$ & -0.00445 & $(0.37)$ \\
\hline Log workplace size squared & 0.00008 & $(1.34)$ & 0.00057 & $(1.52)$ & 0.00139 & $(1.10)$ & -0.00208 & $(1.44)$ & 0.00003 & $(0.03)$ \\
\hline Percentage of dismissals & -0.00004 & $(0.61)$ & 0.00009 & $(0.28)$ & 0.00076 & $(0.67)$ & 0.00046 & $(0.44)$ & -0.00127 & $(1.77)$ \\
\hline Percentage of redundancies & 0.00002 & $(1.36)$ & 0.00049 & $(3.55)$ & 0.00111 & $(2.09)$ & -0.00102 & $(2.33)$ & -0.00060 & $(1.51)$ \\
\hline Percentage of suspensions & -0.00022 & $(0.54)$ & 0.00094 & $(0.35)$ & -0.00741 & $(0.79)$ & 0.00707 & $(0.71)$ & -0.00037 & $(0.05)$ \\
\hline Chi Squared & \multicolumn{10}{|c|}{$5591.04 p=[0.000]$} \\
\hline \multirow[t]{2}{*}{ PANEL B: INFORMATION \& COMMUNICATION } & \multicolumn{2}{|c|}{$C L I=0$} & \multicolumn{2}{|c|}{$C L I=1$} & \multicolumn{2}{|c|}{$C L I=2$} & \multicolumn{2}{|c|}{$C L I=3$} & \multicolumn{2}{|c|}{$C L I=4$} \\
\hline & M.E. & $\underline{T S T A T}$ & M.E. & $\underline{T S T A T}$ & M.E. & $\underline{T S T A T}$ & M.E. & $\underline{T S T A T}$ & M.E. & $\underline{T S T A T}$ \\
\hline Information and Communication & -0.00699 & $(11.09)$ & -0.03943 & (6.59) & -0.11968 & $(33.88)$ & 0.05323 & $(10.99)$ & 0.11286 & $(31.70)$ \\
\hline Chi Squared & \multicolumn{10}{|c|}{$3829.38 p=[0.000]$} \\
\hline \multirow[t]{2}{*}{ PANEL C: INVOLVEMENT \& PARTICIPATION } & \multicolumn{2}{|c|}{$C L I=0$} & \multicolumn{2}{|c|}{$C L I=1$} & \multicolumn{2}{|c|}{$C L I=2$} & \multicolumn{2}{|c|}{$C L I=3$} & \multicolumn{2}{|c|}{$C L I=4$} \\
\hline & M.E. & $\underline{T S T A T}$ & M.E. & $\underline{T S T A T}$ & M.E. & $\underline{T S T A T}$ & M.E. & $\underline{T S T A T}$ & M.E. & $\underline{T S T A T}$ \\
\hline Employee Involvement and Participation & -0.00548 & $(7.26)$ & -0.04304 & $(5.69)$ & -0.15399 & $(36.48)$ & 0.06265 & $(11.47)$ & 0.13986 & $(35.81)$ \\
\hline Chi Squared & & & & & $172.51 p=$ & $0.000]$ & & & & \\
\hline \multirow[t]{2}{*}{ PANEL D: ORGANIZATIONAL TRUST } & \multicolumn{2}{|c|}{$C L I=0$} & \multicolumn{2}{|c|}{$C L I=1$} & \multicolumn{2}{|c|}{$C L I=2$} & & & & \\
\hline & M.E. & $\underline{T S T A T}$ & M.E. & $\underline{T S T A T}$ & M.E. & $\underline{T S T A T}$ & M.E. & $\underline{T S T A T}$ & M.E. & $\underline{T S T A T}$ \\
\hline Organizational Trust & -0.00871 & $(12.44)$ & -0.04236 & $(5.04)$ & -0.12601 & $(30.96)$ & 0.04799 & $(8.93)$ & 0.12909 & $(33.00)$ \\
\hline Chi Squared & & & & & $471.14 p$ & $0.000]$ & & & & \\
\hline OBSERVATIONS & & & & & 17,2 & & & & & \\
\hline
\end{tabular}

Notes: M.E. Denotes marginal effect. Results are from a generalized ordered probit specification allowing for clustering effects within workplaces. Controls in Panels B-D as in Panel A. 
TABLE 5: THE RELATIONSHIP BETWEEN WORKPLACE PERFORMANCE AND EMPLOYEE CLI: WORKPLACE LEVEL ANALYSIS

PANEL A: AVERAGE EMPLOYEE COMMITMENT-LOYALTY INDEX WITHIN THE WORKPLACE

\begin{tabular}{|c|c|c|c|c|c|c|c|c|}
\hline & \multicolumn{4}{|c|}{ LABOR PRODUCTIVITY $(L P)$} & \multicolumn{4}{|c|}{ FINANCIAL PRODUCTIVITY (FP) } \\
\hline & 0 & 1 & 2 & 3 & 0 & 1 & 2 & 3 \\
\hline
\end{tabular}

PANEL B: AVERAGE EMPLOYEE COMMITMENT-LOYALTY INDEX BY OCCUPATION WITHIN THE WORKPLACE

\begin{tabular}{|c|c|c|c|c|c|c|c|c|}
\hline \multirow[b]{2}{*}{ OCCUPATIONAL GROUP $\times \overline{C L I}$} & \multicolumn{4}{|c|}{ LABOR PRODUCTIVITY $(L P)$} & \multicolumn{4}{|c|}{ FINANCIAL PRODUCTIVITY (FP) } \\
\hline & 0 & 1 & 2 & 3 & 0 & 1 & 2 & 3 \\
\hline Associate professional and technical & $-0.0360^{*}$ & -0.0202 & $-0.0031^{*}$ & $0.0594^{*}$ & $-0.0312^{*}$ & -0.0172 & $-0.0048^{*}$ & 0.0532 \\
\hline Skilled trades & $-0.0267^{*}$ & $0.0366^{*}$ & $-0.0415^{*}$ & 0.0315 & $-0.0195^{*}$ & 0.0388 & -0.0025 & $0.0255^{*}$ \\
\hline Personal service & $-0.0375^{*}$ & $-0.0399^{*}$ & $0.0284^{*}$ & 0.0490 & -0.0460 & -0.0288 & -0.0363 & 0.1110 \\
\hline Sales and customer service & $-0.0312^{*}$ & 0.0262 & $-0.0213^{*}$ & 0.0262 & $-0.0273^{*}$ & 0.0437 & -0.0268 & $0.0103^{*}$ \\
\hline $\begin{array}{l}\text { Wald Chi Squared } \\
\text { Pseudo R Squared }\end{array}$ & \multicolumn{4}{|c|}{$\begin{array}{c}248.79 p=[0.000] \\
0.0919\end{array}$} & \multicolumn{4}{|c|}{$\begin{array}{c}342.44 p=[0.000] \\
0.0862\end{array}$} \\
\hline OBSERVATIONS & \multicolumn{8}{|c|}{1,432} \\
\hline
\end{tabular}

Notes: Marginal effects are shown for $L P$ and $F P$. T statistics are shown in parenthesis. A generalized ordered probit specification is used to model $L P$ and $F P$. Controls include: average wage; quadratic in workplace size; quadratic in workplace age; index of labor costs as a proportion of sales revenue; proportions of females, ethnic origin, unskilled; foreign ownership; UK multinational; trade union recognition; performance related pay or employee share ownership; public sector and industry dummy variables. * denotes statistical significance at the 5 per cent level from a joint test of the null hypothesis that on the $\overline{C L I}$ coefficient plus the differential slope coefficient (i.e. $\overline{C L I}$ interacted with specific occupational indicators) are equal to zero. 